GRZEGORZ PAC

Instytut Historyczny

Uniwersytetu Warszawskiego

\title{
CHRYSTIANIZACJA I PRAWO WE WCZEŚNIEJSZYM ŚREDNIOWIECZU
}

Dla historyka zajmującego się wcześniejszym średniowieczem podjęcie tematu chrystianizacji jest tyleż nieuniknione, co niełatwe, rozmaite aspekty tego zjawiska są bowiem przedmiotem rozważań mediewistyki od pokoleń. Mimo jednak tak długiej tradycji badawczej samo pojęcie pozostaje niedoprecyzowane, a historycy - niekiedy w zależności od własny potrzeb - rozumieją je rozmaicie.

Próbę typologii zaproponował niedawno francuski mediewista Bruno Dumézil. Rozróżnia on mianowicie ewangelizację, którą rozumie jako rozpowszechnianie orędzia chrześcijańskiego wśród niechrześcijan, i chrystianizację, którego to terminu używa w odniesieniu do „zjawisk związanych z postępami chrześcijaństwa na obszarach już ewangelizowanych, gdzie większość ludzi przyjęła chrzest" ${ }^{1}$. Punktem przełomowym będzie tu oczywiście konwersja; chrystianizacja w tym rozumieniu zaczyna się więc dopiero po niej.

Warto jednak zwrócić uwagę, że Dumézil, którego monografia poświęcona konwersji królestw barbarzyńskich kończy się na wieku VIII, tworząc swą typologię, znajdował się w sytuacji dość komfortowej. Jako że jasne jest, iż w przyjętym przez niego przedziale chronologicznym „postęp chrześcijaństwa" wśród nawróconych ludów ciągle się dokonywał, nie musiał on właściwie określać jego punktu docelowego. Gdyby jednak chcieć spojrzeć w szerszej perspektywie czasowej, okaże się, że uznanie chrystianizacji za proces o nieokreślonym momencie zakończenia (czy

${ }^{1}$ B. Dumézil, Chrześcijańskie korzenie Europy, Kęty 2008 (oryg. franc. 2005), s. 6-12 (cytat: s. 10-11). 
zgoła nie mający końca) sprawia, iż pojęcie to może stać się tak szerokie, że właściwie nieużyteczne.

W tym sensie lepiej ujmuje to zagadnienie lapidarna definicja chrystianizacji jako „procesu, w wyniku którego społeczeństwo staje się chrześcijańskie”, zaproponowana przez Redakcje „Kwartalnika Historycznego”; towarzyszy jej pytanie, jak owo społeczeństwo chrześcijańskie zdefiniować. Tu jednak pojawia się kłopot, żaden bowiem z zaproponowanych do rozważenia przez Redakcję wyróżników w odniesieniu do interesującej mnie epoki nie oddaje - jak sądzę - istoty sprawy. Oczywiście przyjęcie chrztu przez znaczną część społeczeństwa, a więc jego konwersję, uznać trzeba za warunek sine qua non, ale czy rzeczywiście formalne przyjęcie wiary wystarczy? Można też zapewne zgodzić się, że konieczne jest przyswojenie pewnych prawd wiary, w bardzo podstawowym jednak zakresie. Chrześcijaństwo nie jest bowiem religią „dla wtajemniczonych” i nigdy chyba w jego historii większość wiernych nie znała całości doktryny, a zapewne i nie rozumiała credo. Podobnie rzecz ma się z przestrzeganiem głoszonych przez Kościół zasad moralnych. Doktryna chrześcijańska nie przyjmuje bowiem, że bycie chrześcijaninem wymaga jakiegoś poziomu moralnej doskonałości, a stwierdzenie, że społeczeństwo chrześcijańskie to takie, którego członkowie postępują zgodnie z obowiązującymi w tej religii zasadami, nie wiązałoby tego pojęcia z ziemską rzeczywistością, ale raczej przenosiło je w eschatologię.

Pojawia się też pytanie, jak owe wyróżniki, mające pomóc nam zdefiniować, czym jest społeczeństwo chrześcijańskie, mają się do tego, jak rozumieli je ludzie epoki.Zauważmy, że wszystkie wymienione tu kwestie odnoszą się ostatecznie do decyzji jednostek, ani bowiem przekonania religijne, ani postępowanie moralne (przynajmniej w niektórych swych aspektach) nie podlegają pełnej kontroli, a więc i zewnętrznemu, społecznemu przymusowi. Tymczasem narzucające się z naszego punktu widzenia traktowanie religii w kategorii wyborów i postaw indywidualnych w odniesieniu do wcześniejszego średniowiecza jest do pewnego stopnia nieadekwatne. Dotyczy to także aktu przyjęcia wiary; jak stwierdza Nora Berend, „w interesujących nas społeczeństwach konwersja była kwestią identyfikacji zbiorowej, jako że religia tak przed, jak i po chrystianizacji stanowiła centrum życia społecznego" ${ }^{2}$.W efekcie podczas gdy Redakcja „Kwartalnika Historycznego” pyta, „czy o pełnej chrystianizacji można mówić tylko wtedy,

${ }^{2}$ „In the societies under investigation, conversion was a question of collective identity, as religion both before and after Christianization was central to social life", N. Berend, Introduction, w: Christianization and the Rise of Christian Monarchy. Scandinavia, Central Europe and Rus'c.900-1200, red. eadem, Cambridge 2007, s. 3. 
gdy chrześcijaństwo staje się religią państwową?", w odniesieniu do wcześniejszego średniowiecza myśl tę należałoby raczej odwrócić: bez stania się religią państwową chrystianizacja (w sensie, jaki zaproponował Dumézil) zwykle nie może się nawet zacząć. Wynika to nie tyle (a w każdym razie: nie tylko) z kwestii dysponowania przez władzę odpowiednim aparatem przymusu, dającym nowej religii szanse powodzenia, ile właśnie ze wspomnianego tu rozumienia religii, z trudem dającego się pogodzić z indywidualną konwersją.

Czy ta ostatnia była w ogóle możliwa? Oczywiście, że tak. Na przykład Bruno z Kwerfurtu w swej relacji o pracy misyjnej wśród Pieczyngów wspomina, że w pewnym momencie udało mu się nawrócić około trzydziestu dusz. Pozyskanie grupy wyznawców (nieprzypadkowych zresztą - chodzi, jak się zdaje, o plemienną elitę) to jednak dla Brunona dopiero krok do właściwego celu, który udaje się osiągnąć nieco później. Za spełnienie swej misji uważa on bowiem dopiero moment, gdy - jak sam pisze - „zapanowało prawo chrześcijańskie (christiana lex) wśród najgorszego i najokrutniejszego ludu ze wszystkich pogan żyjących na ziemi" ${ }^{3}$. Pojęcie zastosowane tu przez Brunona nie powinno budzić zdziwienia - w istocie, jak zauważa Robert Bartlett, „chrześcijaństwo było często określane jako «prawo chrześcijańskie (lex christiana)», co trafnie oddaje przekonanie, że chrześcijaństwo dotyczyło tak zasad społecznych zachowań, jak i wierzeń czy praktyk religijnych"4. To samo, stwierdza cytowany autor, dotyczy rozumienia pogaństwa, określanego w źródłach jako „prawo przodków”.

Spośród wzmiankowanych przez niego przykładów przywołajmy tylko jeden, bliski rodzimej tematyce. Wedle relacji Ebona o pomorskiej misji św. Ottona z Bambergu Wolinianie początkowo przegnali biskupa. Dopiero gdy ten nawrócił wielmożów Szczecina, uznający zwierzchność tej metropolii Wolin decyduje się przyjąć nową wiarę. Jego mieszkańcy uzasadniają to właśnie faktem konwersji szczecińskich możnych, a tłumacząc się poniekąd ze swego wcześniejszego postępowania, stwierdzają, że nie mogą złamać „starożytnego prawa naszych ojców i przodków” bez zgody dostojników ${ }^{6}$.

${ }^{3}$ Brunonis Querfurtensis epistola ad Henricum regem, wyd. J. Karwasińska, MPH s.n., t. 4, cz. 3, Warszawa 1973, s. 100. Tłumaczenie za: Brunon z Kwerfurtu, List do króla Henryka II, tłum. K. Abgarowicz, w: Piśmiennictwo czasów Bolesława Chrobrego, wstęp i komentarze J. Karwasińska, Warszawa 1966, s. 253.

${ }^{4}$ "Christianity was often termed 'the Christian law (lex christiana)', and the phrase usefully conveys the sense that Christianity involved rules of social conduct as well as cultic belief and practice", R. Bartlett, From Paganism to Christianity In medieval Europe, w: Christianization and the Rise of Christian Monarchy, s. 65.

${ }^{5}$ Ibidem.

${ }^{6}$ Ebonis Vita S. Ottonis episcopi Babenbergensis, wyd. J. Wikarjak, Warszawa 1969, 
Konwersja dokonuje się więc tak, jak dokonuje się w plemieniu zmiana prawa, a decyzji podjętej przez tych, którzy posiadają uprawnienia prawodawcze, podlegają wszyscy jego członkowie. Podobne rozumienie religii znajdziemy i w innych opisach konwersji (abstrahując tu od kwestii, czy oddają one faktyczny przebieg zdarzeń, czy są wyłącznie ilustracją przekonań autorów). Tak oto, wedle relacji Żywotu Pierwszego, zgromadzeni na wiecu Prusowie mieli powiedzieć św. Wojciechowi i jego towarzyszom: „Nas i cały ten kraj [--] obowiązuje wspólne prawo i jeden sposób życia. Wy zaś, którzy rządzicie się innym i nieznanym prawem, jeżeli tej nocy się nie oddalicie, jutro zostaniecie ścięci"8. Chrześcijańskich misjonarzy od Prusów odróżnia więc przede wszystkim prawo, to zaś obowiązuje bez wyjątku całe plemię i wszystkich jego członków. Rzecz uwidacznia się jeszcze mocniej w tekście napisanym ponad sto lat później, ale dotyczącym wydarzenia niemal współczesnego męczeństwu św. Wojciecha, a więc w słynnej relacji o nawróceniu Islandii pióra Ariego. Zgromadzeni na wiecu Islandczycy podzielić się mieli mianowicie na dwie partie - zwolenników konwersji i obrońców starej wiary. Obie grupy postanawiają, że nie będą dłużej kierować się wspólnym prawem, a przed liderem frakcji konwersji jego zwolennicy stawiają zadanie wyłożenia kształtu legislacji chrześcijańskiej. Ostatecznie przywódca partii antychrześcijańskiej stwierdza, że obowiązywanie dwóch różnych praw prowadzić musi niechybnie do zerwania panującego na wyspie pokoju. Nawołuje więc, aby wszyscy mieli „to samo prawo i ten sam obyczaj". I rzeczywiście: ustanowione zostają prawa nakazujące wszystkim przyjęcie chrześcijaństwa (choć prywatny kult pogański pozostaje dozwolony) ${ }^{9}$.

Relacja ta, odzwierciedlająca specyfikę pozbawionej mocnej władzy królewskiej Islandii, doskonale oddaje istotę sprawy. Przyjęcie nowej wiary wiąże się w sposób nieunikniony ze zmianą prawa, a tego dokonać musi zgodnie cały wiec. Mieszkańcy Islandii, decydując się pierwotnie na

MPH s.n., t. 7, cz. 2, ks. II, 11, s. 72. Por. S. Rosik, Conversio gentis Pomeranorum. Studium świadectwa o wydarzeniu (XII wiek), Wrocław 2010, s. 305-306.

${ }^{7}$ Por. R. Rutkowski, Dzięki komu Islandczycy nawrócili się na chrześcijaństwo? Konwersja widziana oczami średniowiecznych autorów, KH 121, 2014, 1, s. 17-18.

8 S. Adalberti Pragensis episcopi et martyris Vita prior, wyd. J. Karwasińska, Warszawa 1962, MPH s.n., t. 4, cz. 1, s. 43. Tłumaczenie za: Jan Kanapariusz, Świętego Wojciecha żywot pierwszy, tłum. B. Kürbis, w: W kręgu żywotów świętego Wojciecha, red. J.A. Spież, Kraków 1997, s. 74.

${ }^{9} \mathrm{Na}$ podstawie tłumaczenia angielskiego w: Íslendingabók - Kristni Saga. The Book of the Icelanders - The Story of the Conversion, tłum. S. Grønlie, London 2006, rozdz. 7, s. 7-9. Por. R. Rutkowski, op. cit., zwł. s. 6-20; O. Vésteinsson, The conversion of the Icelanders, w: Europe around the year 1000, red. P. Urbańczyk, Warszawa 2001, s. 325-342, passim. Za uwagi dotyczące tekstu oryginalnego dziękuję Rafałowi Rutkowskiemu. 
to, że nie będą kierować się jednym prawem, ale dwoma osobnymi prawami, chcieli w istocie dokonać podziału wspólnoty. Warto bowiem pamiętać, że to właśnie odrębność prawna była podstawą odrębności grupowej, w tym plemiennej - nieco upraszając, można powiedzieć, że Frankiem był ten, kto podlegał Lex Salica, a Longobardem ten, kogo obowiązywało Lex Langobardorum ${ }^{10}$. Mając w pamięci przedstawione przed chwilą opisy konwersji, można by zaryzykować stwierdzenie, że podobnie dla ludzi wczesnego średniowiecza chrześcijaninem był ten, kto podlegał chrześcijańskiemu prawu, a społeczeństwo chrześcijańskie to takie, w którym ono obowiązuje.

Przyjmowane wraz z chrześcijaństwem nowe prawo było nie tylko inne treściowo. Następowały też istotne zmiany w samym sposobie jego stanowienia. Przede wszystkim konwersja rozpoczynała - jak to określił Karol Modzelewski - „proces laicyzacji pewnych ważnych obszarów życia społecznego", wśród których na pierwszym miejscu wymienić należy fakt odebrania sakralnego miru plemiennemu wiecowi ${ }^{11}$. Pozbawiony tego kluczowego atrybutu wiec tracił na znaczeniu, a w efekcie stanowienie prawa, którego przekazicielem była dotąd tradycja plemienia ${ }^{12}$, przejmował w znacznej mierze król ${ }^{13}$. Legislacja królewska, także dzięki swemu pisanemu charakterowi (co było, rzecz jasna, także konsekwencją konwersji), stawała się nowym, potężnym narzędziem w ręku władcy i wyrazem jego władzy ${ }^{14}$.

Tak oto Karol Wielki, podbiwszy Saksonię, błyskawicznie przystąpił do dławienia oporu właśnie za pomocą ustanowienia dla nowej, nieschrystianizowanej jeszcze części swego władztwa nowych praw, surowo przymuszających do porzucenia starej wiary i przyjęcia chrześcijaństwa. Mówiąc w ich kontekście o owej „pierwszej w dziejach Europy” laicyzacji, Modzelewski zwraca uwagę na wyraźne rozdzielenie czynności związanych

${ }^{10}$ Przyjmuję tu wizję zaproponowaną przez Karola Modzelewskiego (idem, Barbarzyńska Europa, Warszawa 2004, s. 66-99). Nie jest to wszelako pogląd przyjmowany w mediewistyce bezdyskusyjnie, o czym tamże.

${ }^{11}$ Idem, Laicyzacja przez chrzest, w: Sacrum. Obraz i funkcja w społeczeństwie średniowiecznym, red. A. Pieniądz-Skrzypczak, J. Pysiak, Warszawa 2005, s. 112.

12 Por. idem, Legem ipsam vetare non possumus. Królewski kodyfikator wobec potęgi zwyczaju, w: Historia, idee, polityka. Księga dedykowana Profesorowi Janowi Baszkiewiczowi, red. F. Ryszka i in., Warszawa 1995, s. 26-32, passim; R. Michałowski, Podstawy religijne monarchii we wczesnym średniowieczu zachodnioeuropejskim. Próba typologii, KH 105, 1998, 4, s. 3-8.

${ }^{13}$ R. Michałowski, Chrystianizacja monarchii piastowskiej w X-XI wieku, w: Animarum cultura. Studia nad kultura religijna na ziemiach polskich $w$ średniowieczu, t. 1: Struktury kościelno-polityczne, red. H. Manikowska, W. Brojer, Warszawa 2008, s. 28. Por. K. Modzelewski, Barbarzyńska Europa, s. 460.

${ }^{14}$ Por. N. Berend, J. Laszlovszky, B.Z. Szakács, The kingdom of Hungary, w: Christianization and the Rise of Christian Monarchy, s. 344. 
z legislacją i kultu nowej religii ${ }^{15}$. Podczas gdy w czasach pogańskich elementy religijne były trwale wplecione w zgromadzenie sądowe, Karol bez zwłoki wprowadził w Saksonii obowiązującą w jego kraju zasadę, ,aby nie odbywać sądów wiecowych i publicznych zgromadzeń w niedzielę", nakazując jednocześnie uczestnictwo tego dnia w Eucharystii ${ }^{16}$.

Oczywiście nie oznacza to, że nowe prawo było w jakimkolwiek sensie świeckie. Nie tylko bowiem wprowadzało ono szereg norm odnoszących się do kultu i zasad moralności chrześcijańskiej (jak choćby ta przywołana tutaj, odnosząca się do świętowania niedzieli), ale też bez wątpienia legislatorzy chrześcijańscy dzielili z poganami przekonanie o tym, że prawo powinno stać na straży ładu wyznaczanego przez religijne nakazy i zakazy. Skoro bowiem - jak wierzono - obraza Boga, dokonana przez jednego z członków wspólnoty, może ściągnąć na cały lud karę i pomstę Bożą, to obowiązkiem rządzących (a zarazem kwestią zbawienia ich i ich poddanych) jest zapewnić, aby prawo Boże było przestrzegane ${ }^{17}$. W tym właśnie przekonaniu widzieć można źródło legislacji w świeżo schrystianizowanych krajach, w których władcy zobowiązywali poddanych do przestrzegania, niekiedy bardzo surowych, norm związanych z nowo przyjętą religią ${ }^{18}$. Radykalny przymus konwersji zastosowany wobec poddanych, wpisany w normy prawne, w jakimś sensie trafiał w kluczowy punkt zachodzącego procesu $-\mathrm{z}$ jednej strony nowe prawo było wyraźnie chrześcijańskie, z drugiej - wprowadzone przez władcę, w efekcie więc obie kwestie były ze sobą ściśle powiązane, a praktykowanie wiary stawało się poniekąd papierkiem lakmusowym akceptacji królewskiego autorytetu.

Zauważmy jednak, że znaczenie prawa nie dotyczy tylko momentu przyjmowania nowej wiary, a uznanie go za czynnik kluczowy w interesującym nas temacie pozwala do pewnego stopnia przełamać zaproponowane przez Dumézila rozróżnienie konwersji i chrystianizacji. Z jednej bowiem strony zmiana prawa - jak pokazywałem wyżej — była dla konwersji elementem najważniejszym, to ona decydowała - w rozumieniu ludzi epoki - że dany lud stawał się chrześcijański. Z drugiej strony oddziaływanie chrześcijańskich praw (niezależnie od tego, na którym etapie chrystianiza-

${ }^{15}$ K. Modzelewski, Laicyzacja przez chrzest, s. 112-113.

${ }^{16}$ Capitulatio de partibus Saxoniae, wyd. A. Boretius, MGH Capitularia regum Francorum, t. 1, Hannoverae 1883, cap. 18, s. 69.

${ }^{17}$ R. Michałowski, Chrystianizacja monarchii piastowskiej, s. 31-36.

${ }^{18}$ Moje refleksje na ten temat wiele zawdzięczają referatowi Marcina R. Pauka, „Washing Hands in a Sinner's Blood: Ducal Power, Law and Religious Zeal in the Process of Central European Christianization", którego miałem przyjemność wysłuchać na International Congress on Medieval Studies w Kalamazoo w maju 2013. 
cji powstawały $)^{19}$ miało - z natury rzeczy - charakter długotrwały, a także dotykało (jak zauważa Roman Michałowski w odniesieniu do odnotowanych przez Thietmara norm wprowadzonych przez Bolesława Chrobrego) „ogółu społeczeństwa, wszystkich jego warstw, o tyle oczywiście, o ile nierozwinięty jeszcze aparat państwowy [--] potrafił skontrolować zachowanie poddanych" 20 .

Oznacza to, że przepisy prawa miały faktyczną siłę chrystianizacyjną, to znaczy, że wymusić mogły w szerokich masach społecznych porzucenie kultu pogańskiego, uczestnictwo w kulcie nowej religii, a także przestrzeganie (w stopniu, w jakim ta podlega kontroli) zasad chrześcijańskiej moralności i ustanowionych przez Kościół norm. Analiza wczesnych praw norweskich, dokonana przez Alexandrę Sanmark ${ }^{21}$, pokazuje, jak głęboko owe przepisy ingerowały w życie codzienne. Poza zakazami dotyczącymi praktykowania pogaństwa i magii, ale też zwalczaniem dzieciobójstwa i poligamii, normowały one sprawy zawierania małżeństw, zobowiązywały do chrzczenia dzieci, określały kwestie związane z pogrzebami, wreszcie nakazywały przestrzeganie szeregu postów i właściwe obchodzenie niedziel i świąt. Te ostatnie miały być czczone także poprzez sąsiedzkie biesiady, na których, podobnie jak na stypach, prawo wymagało obecności kapłana, co niewątpliwie motywowane było troską, aby te pogańskie co do swego źródła imprezy nie zatraciły narzuconego im, chrześcijańskiego znaczenia.Jeśli dodać do tego, że przepisy zobowiązywały księży do informowania wiernych o nadchodzących wspomnieniach świętych i innych uroczystościach, a także o związanych z nimi postach, otrzymamy obraz prawa, które poza zewnętrznym wymuszaniem zachowań zgodnych z chrześcijańskimi normami - posiada także trudne do przecenienia możliwości kształtowania trwalszych postaw i wpływania na internalizowanie kościelnego nauczania przez wiernych.

Jeśli więc chcemy w chrystianizacji widzieć „proces, w wyniku którego społeczeństwo staje się chrześcijańskie", to uznać należy, że z perspektywy ludzi wcześniejszego średniowiecza stawało się ono takim przede wszystkim wraz z przyjęciem chrześcijańskiego prawa.Jeśli zaś - patrząc zapewne bardziej z naszego już punktu widzenia - chcemy społeczeństwo chrześcijańskie definiować przez poziom akceptacji doktryny i uczestnictwa w kulcie, a także stosunek do narzucanych przez Kościół norm, przyjdzie nam wskazać także prawo jako czynnik o pierwszorzędnym w średniowieczu znaczeniu dla zmian zachowań i postaw ludzi we wszystkich tych obszarach.

19 Por. N. Berend, op. cit., s. 29-30.

${ }^{20}$ R. Michałowski, Chrystianizacja monarchii piastowskiej, s. 28.

${ }^{21}$ A. Sanmark, Power and Conversion - a Comparative Study of Christianization in Scandinavia, Uppsala 2004, s. 147-291. 